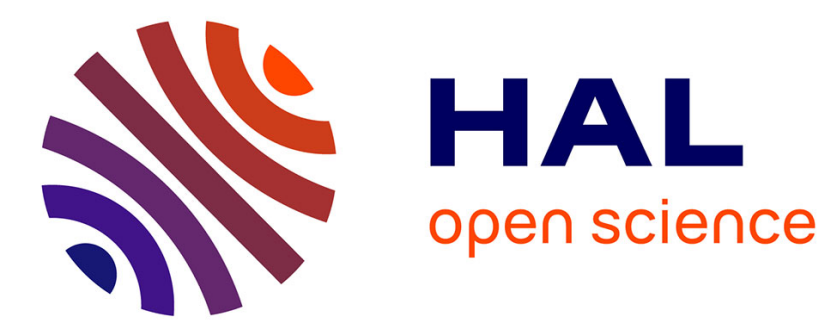

\title{
Being a Tourist as a Chosen Experience in a Proximity Destination
}

Inmaculada Diaz Soria

\section{To cite this version:}

Inmaculada Diaz Soria. Being a Tourist as a Chosen Experience in a Proximity Destination. Tourism Geographies, 2016, Proximity and Intraregional Aspects of Tourism, 19 (1), pp.96-117. 10.1080/14616688.2016.1214976 . halshs-01371723

\section{HAL Id: halshs-01371723 \\ https://shs.hal.science/halshs-01371723}

Submitted on 27 Sep 2016

HAL is a multi-disciplinary open access archive for the deposit and dissemination of scientific research documents, whether they are published or not. The documents may come from teaching and research institutions in France or abroad, or from public or private research centers.
L'archive ouverte pluridisciplinaire HAL, est destinée au dépôt et à la diffusion de documents scientifiques de niveau recherche, publiés ou non, émanant des établissements d'enseignement et de recherche français ou étrangers, des laboratoires publics ou privés.

\section{(1)(1) $\$(0)$}

Distributed under a Creative Commons Attribution - NonCommercial - ShareAlikel 4.0 


\title{
TITLE: Being a Tourist as a Chosen Experience in a Proximity Destination
}

\section{Author: Inmaculada DIAZ-SORIA, PhD candidate - CERTOP, Université de Toulouse-Jean Jaurès}

\begin{abstract}
:
Being a tourist isn't a passive attitude. It is the result of a conscious decision essentially based onhow individuals build what they perceive as unknown and how they decide to get to know it. In other words, tourists deliberately create a distance with the destination which allows them to enjoy the tourist experience as something exceptional. This paper is part of an ongoing research and focuses on the subjective construction of the otherness, since this process determines what is left to be discovered.
\end{abstract}

First, a theoretical overview will introduce the concepts of usual environment, proximity and tourist.Then, we will focus on guided tours as a mechanism of mediation between individuals and places. Finally, we will move on to the case of Barcelona's walking tours and the local participants' experience as a way to adopt a tourist's approach.

Preliminary results show, first, four categories of experience of proximate guided tours: educational, expert, recreational and tourist. Then, they focus on the proximity tourist experience usingUrry and Larsen's notion of the "tourist gaze" and Tuan's theory on the tourist and the resident's points of view. According to these theories,participants'motivations andtheir individual frame of reference define a tourist's point of view. Based on that,results show that proximity tourists and traditional tourists share curiosity as motivation but don't have the same points of reference.In spite of that, the feeling of proximity with the destination doesn't constitute a barrier to become a tourist. It is the conscious adoption of the tourist's role which makes the individual gaze upon the visited areas like a tourist, regardless of the proximity with the environment.

This approach of proximity tourism constitutes a way to enhance familiarplaces anddevelop tourism in an environmentally concerned context where proximate destinations are being promoted.

Keywords: Barcelona, guided tours, otherness, proximity, proximity tourism, qualitative methodology, tourist experience, tourist gaze, usual environment.

\section{Introduction}

Being a tourist is usually associated to an exceptional, marginal(Vacher, 2014) experience out of the everyday life. This exceptionality implies adopting a particular perspective.Urry and Larsen (2011) stated that "at least a part of that experience is to gaze upon or view a set of different scenes, of landscapes or townscapes [...] out of the ordinary. When we "go away" we look at the environment with interest and curiosity" (p. 1). How is this "tourist gaze" adopted when going away means staying in a close and familiar environment? Indeed, in a globalised context there is a distortion between what is perceived as familiar and what is strange (Govers, Van Hecke, 
\&Cabus, 2008). Therefore, otherness can be perceived as much in geographically distantenvironments as in closer ones.

In this context, there is a development of propositions allowing local populations to discover or rediscover their hometowns from different points of view. Some of these initiatives are proposed to local population and tourists alike,challengingthe classical dichotomy tourist-inhabitant (Fabry, Picon-Lefebvre, \& Pradel, 2015). Guided walking tours essentially made for a local audience are also part of this phenomenon. They have essentially been developed in metropoles like Paris where organisations like Promenades urbaines(Aguas \& Gouyette, 2011) invite "discerning strollers,informed residents and enlightened tourists" to "urban walks allowing them to acquire the capacity to do a critical reading of the visited spaces"(Promenades Urbaines website). In Perth, for example,Eat the Street Walking Tours give the possibility to tourists and residents to discover the city through its bars and gastronomy. Barcelona has developed since 2008 a sector of small companies of walking tours where the majority of the participants live in its metropolitan region.

This paper is part of an ongoing research with focus on the subjective relationship between individual, tourist activity and proximate destination. The goal is to understand if it is possible to become a tourist in a close and familiar environment and how individuals engage in this experience. This paper focus onthe experience of walking guided tours as a mean to become tourists in the own hometown. The hypothesis of research is that tourism provides a particular and intentional point of view. In other words, that a tourist's point of view can deliberately be adopted allowing individuals perception of the otherness in a familiar context. Therefore, on one hand, walking guided tours are considered a tourist practice and tourism is here a mean to get access to the unknown aspects of a familiar environment. On the other hand, being a tourist is an intentionalapproach constituted by a particular way to experience which transforms everyday temporality and spatiality(Vergopoulos, 2013).

The implications of this idea include new opportunities for the tourist sector, especially in an environmentally concerned context where proximate destinations are being enhanced. Moreover, the valorisation of familiarplaces thanks to the development of proximitytourism could be important in the construction of oneself and of society. This is especially relevantin a context where place matters (Florida, 2008), heritage is being promoted and local identities reinforced as a reaction to the globalised context (Arrieta Urtizberea, Hernández León, \& Andreu Tomàs, 2016).

Firstly, a theoretical review of proximity tourism will introduce the subject. Secondly, the ethnographic methodology, whose aim istodefine proximity touristand how he/she buildsa tourist approach, will be explained. Then, preliminary results will be presented from a qualitative perspective. First, the experience of proximate walking guided tours has been categorised in four kinds of experience. Then, individual's motivations and his/her frame of reference have been analysed as the basis of the tourist experience. The final conclusions will summarisethe most important ideas and will introduce further questions for future research. 


\section{What does Proximity Tourism mean?}

How is it possible to visit a place in a tourist way when this place is close to our own household and feels familiar? Tourism has traditionally been defined as the activity allowing people to visit places outside their usual environment. Many authors have theorised about this idea of usual environment, about its meaning and physical perimeter (Smith, 1999). While the official definition refers to the "geographical limits within which the individual conducts his/her regular life routines"(WTO, 2014, p. 12), some authors challenge this notion of geographical distance and consider it inadequate to analyse this idea (Govers et al., 2008). For some, in a post-modern era characterised by "globalisation, hyper-consumerism, the experience economy and new developments in technology" (Smith, MacLeod \& Hart Robenson, 2010), the limits between work and leisure as well as those between everyday practices and tourist practices are not clearly defined (Vacher, 2014).This increases the complexity of defining what is part of the usual environment and what is not. Moreover, itreinforces a reinterpretation of the spatiality and temporality of proximity (Bourdeau, 2009).

There is not a consensus in the definition of proximity. This is a complex concept with multiple dimensions (Boschma, 2004). On one hand, it is physicalwhen it can be measured in kilometres, miles, etc. On the other hand, it has an abstract dimension based on organisational parameters or on individual perceptions (Torré, 2004). Guedon(2005) uses the concept of "social proximity" to explain this abstract dimension, conditioned by individuals' experiences, their system of representations and theirperception of proximity (p. 11). We will use the more general notion of "abstract proximity", which is measured in terms of familiarity (Boschma, 2004; Torré, 2004). These different dimensions of proximity are not necessarily opposed, the closest area to an individual's home might or might not feel familiar. This distinction just helps to understand different ways of defining this concept.

From a spatial point of view, proximity tourism has mainly been studied as a recent phenomenon, related first of all to the increase of environmental awareness (Dubois \& Ceron, 2006; Dubois, Peeters, Ceron, \& Gössling, 2011; Jeuring, 2015) and, second of all, as an mechanism of adaptation in a context of economic crisis (Callot, 2013). This is when travelling far is not possible anymore, tourists would choose closer destinations. Other authors, like Pearce (2012) are interested in analysing the fact of travelling to familiar places, destinations that tourists already know from previous life experiences. For example, they used to live there or they studied there or they have some sort of connection to that place which makes it familiar. If we accept this idea of an abstract dimension of proximity, travelling to familiar but distant places would be a kind of proximity tourism since this tourist would be travelling inside his/her own abstract perimeter of proximity.

In the case of individuals analysed in this research, they participate in guided tours and they live in the area where these tours take place. Therefore, they could be considered as proximity tourists in both the physical and the abstract dimensions of proximity since a priori this area is familiar to 
them. This approach is quite novel in tourist studies since these practices have mostly been analysed with foreign participants (Larsen \& Widtfeldt Meged, 2013; Zillinger, Jonasson, \& Adolfsson, 2012) and the perspective chosen to analyse the participant's approach towards the visited places has mainly been done in terms of satisfaction (Geva \& Goldman, 2008; Hughes, 1991). This research looks at this approach from a philosophical perspective analysing the experience of becoming tourists.

In a context of intense mobilities where those individuals classified as residents, inhabitants or hosts, might or might not live permanently in their main residence, tourists could also be considered as temporary inhabitants of the destination (Stock, 2007). Their stay is just a priori shorter than the residents' stay. This approach gives tourists a deeper meaning, because they are not just mere figures in transit (Pradel, Simon, \& Lefrançois, 2015). Furthermore, following the performing tourism approach (Edensor, 2001; Haldrup \& Baerenholdt, 2011; Haldrup \& Larsen, 2009),tourists become producers of their experience as well as producers of the destination.Guided tours have already been analysed using this approach (Jonasson \& Scherle, 2012; Larsen \& Widtfeldt Meged, 2013).It facilitates the analysis of participants whether they are traditional tourists or locals visiting their hometown. That is because, in the case of proximity tourists, they aresimultaneously tourists and residents. This approach allows to simplify the analysis by supressing the distinctions between these two categories (Fabry et al., 2015).

Besides, in a global context where individuals can work from almost anywhere as long as they are connected to the world through the technologies of information and communication (Ascher, 2000), choosing where to live can meet recreational needs. That is what some authors call amenity migrations (Bourdeau, 2013). This phenomenon makes the distinction between tourism and everyday life even blurrier.

In this context, if tourism brings people outside of their usual environment, doing tourism at a micro local scale is possible, even when the visited places are not only close but also familiar. That is adopting the tourist gaze (Urry \& Larsen, 2011). When the geographical trip is not necessary in order to practice tourism, when one can be a tourist in his/her own region, being a tourist means adopting a different point of view. In this situation, tourists'point of view is based on curiosity (Vergopoulos \& Flon, 2012) as they approach the visited placesdifferently, looking for the unknown.

It is from this perspective that we consider individuals analysed in this research as tourists. When they take part in walking guided tours, they change their role. They are no longer residents or just any kind of users of the public space: they gaze upon their town and interact withitlike tourists. They travel in time through the guide's narrative(Bryon, 2012; Gellereau, 2005; Karrbom Gustavsson \& Hallin, 2013).

Tuan states that tourists' point of view is simple since it is confronted to the unknown, to the novelty of the visited environment so tourists express themselves freely. On the opposite, residents point of view is complex because it is totally immersed in the environment. For this 
reason, they find indirect ways to express themselves, like behaviour, local traditions, folklore, myths, etc. Moreover, tourists would mainly point out aesthetical aspects and they would be able to see the visited society's strengths and weaknesses much more clearly than locals (Tuan, 1990). It is interesting to note that individuals analysed in this paper can be considered both tourists and locals. Following Tuan's theory, it would mean that they hold both a simple and a complex point of view on this territory. On one hand, they live in the destination so, according to Tuan, they are totally immersed in it and they express themselves through indirect mechanisms linked to the everyday life. On the other hand, they pretend to be tourists in these same places. During the brief period of time when the guided tour takes place, according to this theory, they are more critical and notice aesthetical aspects of these places more easily than during their everyday life. This double dimension of proximity tourist has been taken into consideration in the analysis carried out for this research.

Furthermore, participant's previous experiences as resident have an influence on their experience of the tour. Tourists also carry with them a vision of the world, a perception code which influences their experience (Urbain, 2002). If "to experience is to learn, it means acting on the given and creating out of the given" (Tuan, 2011, p. 9). It means that previous experiences of any kind (as a resident or during previous trips) condition the current experience (Schütz, 1987). Therefore, both tourists and proximity tourists will experience the guided tour conditioned by their own life experiences. The experience of the guided tour will alsomodifythe way of perceiving and interacting with the places where they live and with places that they will visit in the future. In this sense, the concepts of place and experience are here considered as subjective constructs. This approachhelps to understand how the participants' relationship with places which already had some meaning for them influencestheir experience of the guided tour.

\section{Why Tourism?}

Why do we use tourism as a concept to explain this local phenomenon? The aimfor discovery is traditionally associated with tourism. Urbain (2002) states that tourism is the generalisation of a way of knowledge (p. 120). The main goal of the majority of participants in the activities which constitute the object of this research, as it has been confirmed by the interviews, is to get to know the city better. They want to discover new stories, places and aspects just out of curiosity. This is particularly possible in the urban context since nowadays "the city looks for otherness inside itself when it used to find it naturally outside" (Bourdeau, 2013, p. 25). In other words, urban citizens have traditionally associated otherness with rural, foreign and wild landscapes. However, nowadays, cities are also able toprovide exoticism and otherness.

Officially, these participants should be categorised as excursionists because they go back home at night (WTO, 2014). We could also use the more general notion of visitor who can be an overnight visitor or a same-day visitor. Besides, this practice of guided tours could be considered a leisure activity in the case of these local participants. However, we mostly use the terms tourist and tourism because this research aims to enhance the idea that it is not necessary to go to the other side of the world to find what we could find close to home if we remained available 
(Vacher, 2014, p. 136) for this discovery. In this sense, Vacher states that looking for a marginal experience already creates a distance with the everyday life and makes this experience closer to tourism than leisure(2014). These guided tours where locals participate provide a sort of marginal experience. On the contrary, for a tourist this would be a normal practice, as visiting the city with a guide is part of the experience of many tourists(Larsen \& Widtfeldt Meged, 2013; Zillinger et al., 2012). Hence, it is the thirst for discovery and curiosity as motivations and the exceptionality of the experience which refer to the tourism realm.

As proximity tourists are and feel close to the destination, their impacts might be different or might be analysed differently from traditional tourists' impacts. Tourists produce the destination through their experience and their actions (Edensor, 2001; Haldrup \& Baerenholdt, 2011;

Jonasson \& Scherle, 2012; Larsen \& Widtfeldt Meged, 2013; Prebensen \& Joar Vitterso, 2013), just as stakeholders do with their decisions and policies. As it has been said, these proximity tourists are also everyday users of this area, so they produce it in several ways. On one hand, they do it as residents when they carry their daily practices out and, on the other hand, they do it as tourists during the time of the activity. Through this tourist experience, they do not only contribute to the construction of the destination: this experience also contributes to the construction of oneself, of the tourist's subjectivity and of future experiences (Bossé, 2010; Jackson, White \& Schmierer, 1996; Pearce \& Kang, 2009; Tung \& Ritchie, 2011).

Furthermore, their participation in these activities, their tourist experience, might also have impacts on the ways they will use and interact with these places afterwards, once they become residents again. From this point of view, the hypothesis raised by the printed guides analysed by Vergopoulos (2013), that residents only have a relationship of routine with their territory, that our everyday practices in the city would prevent us to seize its curiosities (p. 58) and that we would only seize them by adopting the tourist gaze would have to be accepted. In this sense, the role of everyday practices (Selby, 2004)and curiosity in the construction of the tourist's point of view will be analysed.

\section{Guided Tours as Mechanisms of Mediation between Citizens and their Cities}

Planning a trip raises many questions. What has to be seen? What would we like to visit? Most tourists choose to participate in guided tours, especially during short trips because these tours concentrate the main highlights of a destination in a brief period of time(Widtfeldt Meged, 2010).Tourists as a group during guided tours are usually stigmatised (Larsen \& Widtfeldt Meged, 2013) comparing to those who travel independently and consider themselves as real travellers. Organised groups are usually undervalued and accused ofjust following the official trails(Christin, 2008).

Walking is a peaceful way of appropriation and re-appropriation of space and time. In a context where walking is relegated to the leisure realm (Le Breton, 2000), walkingtourshave been developed as a regular offer to tourists especially in urban destinations. This research uses the concept of walking guided tours instead of just walking tours to emphasize that there is a guide 
setting the pace of the visit. There are indeed several kinds of similar propositions on foot without a guide. For example, self-guided tours proposed by tourist offices, printed guides, specialised websites or treasure hunts on heritage sites or city's old towns (Beaucham-Aligny, Houvenaghel, \& Wilhelm, 2011; Boudelaire \& Cova, 2008).

However, walking guided toursaren't just a leisure practicelinked to the tourism sphere, they also constitute an appropriation tool for citizens. City councils and associations organise guided tours essentially dedicatedto the local population. They are usually free and divided in two main types. On one hand, we have themed tours, essentially about historical periods and artistic or architectural local elements. For example, French municipalities and regions labelledVille et Pays d'art et d'histoire [Municipalities and Regions of Art and History] regularlyorganise walking guided tours as a mediation mechanism between heritage and local population. This label represents an engagement of local governments towards heritage in order to favour the attachment of the population to its usual environment and develop local identity(Villes et Pays d'Art et d'Histoire website).On the other hand, walking guided tours are organised to introduce local urban projects and infrastructures. When urban planners organise these tours, they constitute a communication tool for institutional stakeholders for purposes of transparency. They also transport the citizen to the future (Karrbom Gustavsson \& Hallin, 2013)since the visited sites don't exist or they aren't operational yet.This kind of tours are also organised by associations or individuals interested in urban development from a critical point of view. For example, Jane's walks are locally organised in cities all around the world where residents share their knowledge of the place where they live in what they call a "walking conversation"(Jane's walk website).

Walking guided tours analysed in this paper have a different approach. They are not free, they cost between $9 €$ and $18 €$.This cost has been interpreted here as a proof of the participants' investment in the activity.Participants live basically in the metropolitan region of the city where the tours take place although there is a minority of traditional tourists among participants too. These are themed tours. The themes include historical periods, neighbourhoods' stories, the places where a figure or a character lived, the places that inspired a book,places where a movie was filmed, important buildings and places fora cultural or a political movement...A priori, they have an educational approach, they aren't necessarily critical like Jane's walks, for example. All the guides in these tours are officialguides because official tours are easier to approach.Unofficialguides usually work with private groups which are harder to observe since they don't allow outsiders. Besides, unofficial guides essentially work with traditional touristswhile this paper focus on proximity tourists.

\section{Barcelona, a Proximity Destination}

Barcelona (Spain) receives visitors from around the world. According to the official statistics, the city received 7,874,941 tourists in 2014(Turisme de Barcelona, Diputació de Barcelona \& Barcelona City Council [TB, DiBa \& BCN City Council], 2015, p. 9). More than four million of them came from European countries and more than 2 million from the rest of the world. These 
figures concerntraditional tourists, according to the WTO's official definition: those who spend at least one night in the destination. Barcelona has not always been a well-known tourist destination. Its tourist development really started after the city hosted the Olympic Games in 1992. Since then, it has developed this sector essentially around the Mediterranean lifestyle(Guàrdia, 2010). Its mild climate and geographical situation next to the sea, as well as a lively public space, have deeply contributed to building and reinforcing this positive image. These features have been enhanced thanks to the urban operations carried out for the Olympics and due to a reorganisation of public stakeholders since then (Jiménez \& Prats, 2006, p. 166).

The result is that Barcelona has been developed as a tourist destination receiving $40 \%$ more tourists in 2014 than in 2005(TB, DiBa \& BCN City Council, 2015). In this context, the tourist pressure is highly perceived by local population (Vlès, 2011), especially in the city-centre where "Tourists go home" signs can be seen hanging from many balconies. With tourism development, prices for residential rents and serviceshave increased (Jiménez \& Prats, 2006), but not the income of the local population. The economic crisis going on since 2008 has exacerbated this gap. The local government elected in 2015 has made this issue a priority and intends to manage tourism in a more sustainable way (Suñé \& Sierra, 2015). Therefore, in the years to come, there should be some changes in the way tourism is managed by public stakeholders and the impacts of their actions will have to be taken into account.

Barcelona is not only a destination for traditional tourists: it also has interesting features which make it popularamong its own population. As one of the interviewed organisers of guided tours states: "Barcelona ... it is impossible to finish it!" (Joan, 35), meaning that Barcelona is 2000 years old and its history is rich in anecdotes soit is possible to go over and over its streets and always find a new way to look at them. Thishas been identified as an opportunityby some entrepreneurs and different companies offer the local population the chance to rediscover their town. This phenomenon isn't exclusive of Barcelona. Small companies, associations and independent guides organise walking guided tours for locals and tourists alike in metropoles from all continents. For example, Manila (De Guzman, 2014), New York (Tumola, 2012), Johannesburg (AFP Relax News, 2012)and Melbourne (Maunder, 2012) have their own walking guided toursto rediscover their history and particularities.

These tours are also of interest for tourists looking for another way to visit the destination.Traditional tourists interviewed in this research declared that participating in this kind of guided tours with locals allows them to get to know the city off the beaten tracks. However, they mainly attract residents from the city or the metropolitan region. The metropolitan regionof Barcelona is a $3,236 \mathrm{~km}^{2}$ area with almost 5 million of inhabitants. It is one of the ten biggest metropolitan areas in Europe and the second in population density after Paris(Esteban, 2003; Sogues, 2010).According to the interviewed organisers, $90 \%$ of their audience lives in this area(see Figure 1). "Tourists come here and know everything and we live here and we don't know our own city" (Gerard, 67). As this participant who lives in the metropolitan regionof Barcelona said in his interview, locals participate in these tours expecting to know Barcelona as tourists do. 
This double-approach of walking guided tours, first, as a tourist activity for locals and, second, as a local activity for tourists is particularly interesting,especiallywhen there are some tensions between the local population and tourists.

Figure 1. Participants' Origins and Visited Areas

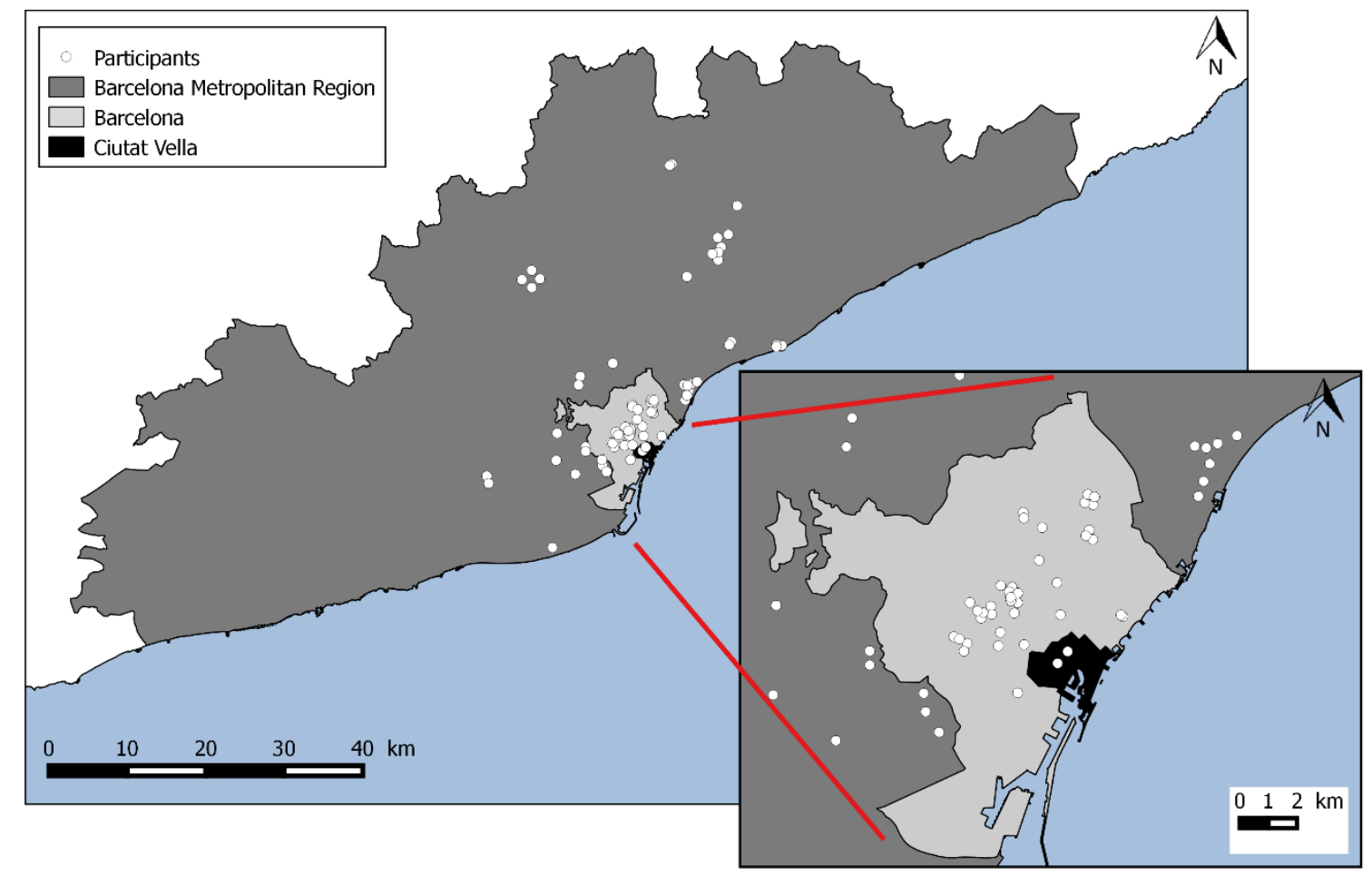

Source: Author using cartographical basis of Institut Cartogràfic de Catalunya and CartoBCN.

Nine companies have been identified in Barcelona asorganisers of these walking guided tours. There are other types of organisers:associations, unofficialguides, etc. However, as previously explained, they haven't been included in the analysis. These activities are not included in the official tourist statistics as they are usually considered part of the leisure offer so it is difficult to calculate their impact. There are not official figures for this practice anyway. These nine companies have been asked about the number of participants they had every year in order to be able to measure the actual impact of this phenomenon. Only five of them make their own statistics so only estimations of the actual figures were provided. Therefore, it is hard to evaluate this practice by analysing its numbers. These tours and traditional tourist walking tours share a spatiality and temporality since they occupy the same streets at the same period of time. They use the public space as tourists but they are not taken into account by public stakeholders when they plan the destination or when they manage public space's uses and flows. 
Most of the tours take place in Ciutat Vella (Old Town), the roman and medieval part of the city (Figure 1). This district is very busy with traditional tourists, local population and commuters. Because it is a crowded and a very popular shopping area, we could think that residents would rather be interested in visiting more unknown areas of the city. However, one of the interviewed organisers said that "at the beginning we tried to avoid Ciutat Vella but people asked for it and finally we had to do it" (Marta, 33). It is not surprising if we consider that this is the 2,000 years old part of the city. As a consequence, it is the part where there is more varied material to create different tours.

In conclusion, Barcelona has been chosen as case study because, on one hand, walking guided tours mainly for locals constitute a thriving sector developing since 2008 and,on the other hand, these activities are concentrated basically in the most crowded as well as the most visited parts of the city so their impacts in terms of use of public space are significant.

\section{Methodology}

This research analyses the point of view of individuals about their experience of walking guided tours in their hometown. The aim is to understand how otherness is built in a close and familiar environment and what role tourism has in this process.

As Petiteau and Pasquier (2001) wroteabout walking as a tool in urban studies: "when an individual questions his/her own references, his/her words are an analysis by themselves whose value and coherence are as powerful and interesting as any expert's analysis"(p. 64). In other words, every individual is capable of providing a valuable story (Davis, 2016, p. 51). Therefore, the researcher maintainsa relationship with the analysed individuals based on trust so their analysis of their own subjectivity is accepted by the researcher as an expert's position.

Ethnographic tools were used in order to collect this subjective data. Thirteen different walking guided tours were observed with a researcher-as-participant approach. At the end of these tours,ninety-three participants shared their experience. All participants were approached and they participated in the research depending on their availability. This method was adopted because observing the tour as a participant helped the researcher to gain the participants' trust (Taylor \& Bogdan, 1987); accordingly, they were more available to be interviewed afterwards. In order to assurethe number of interviews and the quality of the representation, almost all participants in the observed tours filled a form right after the tours. Then,the researcher couldcarry informal interviews at the moment of collecting these forms.

Finally, ninety-three participants filled a form.Seventy-five of them shared their experience through informal interviews.Besides, eighteen semi-structured interviews were conducted with the same topics than the informal ones but with participants who had more time to spend with the researcher. This allowed the researcher to delve into their experiences as traditional tourists and into their previous experiences in guided tours. All the interviewees (in semi-structured and informal interviews) were asked abouttheir hometown, in order to determine the physical 
proximity with the places where the tour took place; participant's previous experiences (everyday practices and memories) in the area of the tour;the experience of the guided tour itself (motivations, favouriteplaces andnarrative...); and repetition (participation in previous tours). Interviews and forms were held in Catalan and Spanish depending on the participant's preference. The answers have been translated into English for this paper but they have been analysed in the original language.

The interviewswere coded and analysed using NVivo. The coding processwas based on these two dimensions: individual's frame of reference and walking guided tour's experience. Firstly, individual's frame of reference includes everything in the individual's experiences which might condition the experience of the tour. The experience is considered as the ensemble of what is before, during and after the experience itself (Schütz, 1987). According to Schütz, what happens before the experience itself contributes to the stock of knowledge then mobilised during the current experience. This stock of knowledge influences how the experience is perceived and lived(Bossé, 2010). The idea of the participant's frame of reference is similar to Schütz' stock of knowledge which includes everything relevant to an actor. In this analysis, the participants' frame of reference is a combination of their biography, everyday practices and memories. Secondly, walking guided tour's experiencerelates to the participants' motivations, their participation in previous tours, their feeling of discovery, as well as the perceptions of the spatiality and temporality of these tours and of the guide's performance. The analysis of walking guided tours is also based on this idea of the experience as a whole.

In summary, for the purpose of this paper, ethnographic tools like participant observation and semi-structured and informal interviews have been used and a qualitative analysis carried out. This methodology aims, first of all, to analysehow walking guided tours are experienced by locals. Second, it intends to understand better the experience of walking tours as tourist practices and their role in the construction of otherness.

\section{Findings and Discussion}

Preliminary results on the links between individuals andproximate destinations based on their participation in walking guided tours will be shared here with the aim of introducing a new approach in tourism studies. Firstly, different categories of experience of participants in these walking guided tours will be introduced. Then, the tourist experience will be analysed in relation with the adoption of a tourist point of view. Tourists experiences are very diverse. For that reason, we refer to a tourist point of view, instead of the tourist point of view. In order to facilitate the reading, participants' statements will be shown in italics.

\section{The Four Experiences of Proximate Walking Guided Tours}

The analysis of motivations of participants in walking guided tours in their metropolitan region has led to four types of experiences: educational, expert, recreational and tourist. Like Cohen's categorization of tourist experiences (1979), this separation in four modes of experience is a 
simplification for analysis purposes. The same participant actually has different experiences within the same tour.

First of all, educational experience relates to those participants taking part in these tours to learn more about the city: "I love the history of the city. [...] I go to all the tours about it, especially to those regardingthe city planning: why is there an alley there? I'm very enthusiastic about streets, about why this square is called like this..." (Roger, 29); "[I participated] out of curiosity, just to learnfurther about things that I don't know well, even having already seen them" (Felipe, 67).These are examples of participants'thirst for knowledge. In this sense, they clearly have expectations about improving their knowledge and they consider that these tours are of "historical and cultural interest" (Chema, 37).

Moreover, for some people, these tours complement or even replace other ways to learn: "We prefer walking on the street and talking to people while they explain its story rather than opening a book and search or do a guided tour in a museum"(Carlos, 48); "On 1972, I started going through the city with a book called Barcelona pam a pam [...]. Since all these tours have started I participate" (Roser, 67). The interesting feature of these tours as an educational experience is the fact that the information is associated to a place;narrative and physical sites are presented as a wholeso it is easier to visualize it and learn: "I've read a lot about the Civil War in Barcelona and I was very interested in visiting the specific places where the facts took place" (Pep, 65); "Historical events are more impressive on the field" (Felipe, 67).

These tours have to be enjoyable to become an alternative source of information to books and other sources: "Instead of just saying «This shop is 150 years old», I prefer when the guide says «Look, the decorations were made by whatshisname...». I prefer that rather than just seeing a building just because it's a building. I like when they explain the facts: why Sagrada Familia has four different kinds of stone, if it is because one kind comes from Montjuï's quarry, the other one from another place...; or why a column is harder because it is built using a harder kind of stone... This is better than just seeing Sagrada Familia as a huge building which will take a lot of time to be finished" (Carlos, 48). Walking tours have an entertaining dimension and they are perceived as a way to learn while having fun.

Traditional guided tours already have an educational aim (Karrbom Gustavsson \& Hallin, 2013) since theyintend to provide information about the visited places. Nevertheless, they are usually stigmatized (Larsen \& Widtfeldt Meged, 2013) as a staged practice where passive tourists follow anestablished path.In spite of the interest in learning, these participants didn't show a very active attitude during participant observation. They asked few questions, usually to confirm that they have heard correctly or that they were looking at the right place and seemed to accept the guide's story unconditionally. Even if these participants live in the metropolitan region of Barcelona, they remain passive and follow the guide through a path which is, by the way, very similar between tours on the same areas. 
Secondly, the expert experience goes one step further than the educational one. In this case, participants position themselves on the same level than the guide. It means that they don't participate in these tours just to learn but also to share their knowledge.In contrast to the educational experience, in the expert experience participants are very active. They ask a lot of questions or make comments during all the tour. For example, they complement what the guide says: "That tradition must have existed since the Greek" (Roser, 67); and they challenge the guide's position about historical assertions:"No,I don't agree. Romans did a lot for us!" (Roser,67), "Sometimes they [guides] are explaining and I think «No, that isn't true» or «The other version is...» and sometimes I have told the guide about this contradiction" (Carlos, 48). They even admit not to believe the guide's story entirely: "I've just been about to tell him: what does this have to do with that?" (Herminia, 56). This way they verbally coproduce the guide's performance thus impacting the other participants' experience.

These participants take part in these tours looking for a confirmation of their knowledge, expecting that the guide will improve it but confidents of what they already know about their hometown. They feel that they know their region well because they show interest in it, in opposition to others who don't: "I participate in these tours since they started being organized because it happens that you live in a place and..., well, there are always people more interested in learning about the place where they live than others, right? For example, many years ago, Valencia and Mallorca streets' directions changed and you can 't imagine the amount of things that you found out running in the opposite sense because you looked at the streets in a different way" (Roser, 67). Therefore, according to the terminology used by the association Promenades Urbaines in Paris to define their audience, these participants correspond tothe categories of discerning strollers and informed residents(PromenadesUrbaines website).

Participants with a professional interest in these tours have also been included in this category: "We've done the architectonical tour of Diagonal Mar and we've also participated in a special tour in Vic, also organized by architects. We are both architects" (Ramón, 60); "I am in this tour because I'm writing a book about the Freemasonry" (Josep, 70). Thislast participant was learning about the subject of his bookand also took the opportunity to spread the word about his previous book. Because of his knowledge of the theme of the tour where he participated he's been categorized as an expert but he didn't really question the guide.He interacted with all the participants though and shared his knowledge about the city with them.

In the third place, recreational experience includes all those participants motivated by having a good time.This experience corresponds toCohen's "recreational" and "diversionary" modes (1979), depending on the secondary motivations. If participating in a tour is like going to the cinema or shopping, then it is just a way to spend the day off and it corresponds with Cohen'sdiversionary experiential mode:"It was an activity with my friends" (Marta, 30); "My sister wanted to participate in a tour like this so it was my Christmas' gift for her: this tour and a lunch afterwards" (Carolina, 55). However, if besides having a good time, participants aim to 
know better the place where they live, this motivation could be considered as a form of recreation of the individual:"I participated to spend a nice day in Barcelona and to know the city better" (Laura, 30). Following Cohen's theory (1979), these participants would have a recreational experience since it "restitutes the individual to his society and its values" (p. 185). It is therefore meaningful because it enhances individual's attachmentto his/her hometown.In this case proximity is relevant because these tours are a tool to bring individuals closer to their region and improve the sense of place, the familiarity with their hometown: "[Tours] help me to know my own territory much better, they help to think more highly of it. I especially like them because sometimes I receive people from abroad and then I can explain my town much better bymyself' (Carolina, 55).

Finally, tourist experience relates to participants aiming to approach the city like tourists do: "It is the first time that I do this in Barcelona. I've done it in Berlin where I've been visiting my daughter and I thought "Why wouldn't I try to do it here?»" (Pep, 65); "It seems ridiculous that you live somewhere and you don't know it and people from other places come and tell you «look, I've been there» and you feel like a fool" (Marc, 63); "We are often ignorant of our own history, our environment, our town... I think that it is also fine to discover, to learn... not only about the places where we travel, the places that we visit, but also about what we have nearby" (Martí, 35).

These four categories help to contextualize the proximity tourist experience. They reflect participants' motivations which condition not only their own experience but sometimes the rest of the group's.First, participants searching for an educational experience are very attentive to the narrative. During the observations, these participants were focused and rarely interruptedthe guide. On the other hand, participants in an expert experience asked many questions and interrupted the guide very often. In this case, guides are forced to get out of their prepared speech. It usually improves the narrative because participants who know the area well coproduce it. The tour is then prolonged, disturbing someother participants: "You usually need two or three hours but three hours are usually prolonged because there is always someone who asks questions, someone bringing something up because he knows more than the guide..." (Carolina, 55).Thirdly, the recreational experience involves not only enjoying the tour but also the city so these participants usually remain behind looking at shop windows or other events going on. Sometimes the guide waits for them to start talking, some other times he doesn't and these participants miss a part of the story. They never complained during the observations though.

Finally, participants in a tourist experiencehave decided to participate in these tours to discover the city like tourists do but, like tourists, they don't have a unique behavior: some of them ask questions, some are very focused on the narrative and some others take pictures so sometimes they remain behind. The next section will get deeper on the proximity tourist experience as a particular perspective.

The Proximity Tourist Experience 
According to the theoretical frame, tourists are defined because of their motivations which are usually based on curiosity (Vergopoulos, 2013). They also gaze upon the destination in a particular way conditioned by individual's references framed by sociocultural conditions(Urry \& Larsen, 2011). Besides, they point out aesthetical aspects of the destination and see more easily the strengths and weaknesses of it because they hold a simple point of view (Tuan, 1990). In which way does the proximity tourist experience meet these conditions? Is the term "tourist experience" appropriate in this case?

According to the analysis, curiosity is undeniably one of the main motivations for participants in these walking guided tours: "I participated out of curiosity, to learn about my town" (Laura, 31); "I participated because I was curious about Freemasonry" (Azucena, 60); "I was curious about my city" (Mari, 40), etc. According to Urry and Larsen (2011), curiosity and interest influence the way we perceive the environment. In other words, there is a predisposition in the way of appreciating the activity and the visited areas when this approach is motivated by curiosity. Following up with their theory, the tourist gaze is conditioned by this motivation, as well as by individual's frame of reference.

The analysis of participant's frame of reference has been based here on the hometown and residential biography, everyday practices and memories. That is all the subjective and collective elements which condition the individual perception of the experience and,therefore, the proximity tourist gaze.Firstly, when participants live in the metropolitan region of the visited area, they are proximity tourists from a physical point of view.However,hometown is usually considered as part of the usual environment, soa tourist should keep a distance from it, according to the official definitions (WTO, 2014). Figure 1 shows that the interviewed participants in thesewalking guided tours live in the metropolitan region of Barcelona, 37 of them in Barcelona city. This physical proximity has an impact on the experience. On one hand, for some it is the motivation to participate in these activities: "That is why I like these tours, because you learn about your home and there are a lot of things that you don't know yet about it" (Sara, 51); "I participated to learn about areas in Barcelona that I didn't know before, I want to learn about its neighbourhoods" (Judit, 28); "I love my city and also love to widen my culture" (Dolors, 42); "I wanted to learn more things about my city" (Xavi, 29), etc. According to these statements, it looks like physical proximity is a driving force for these activities. When there is the feeling that there are unknown aspects of the own culture, walking guided tours become a mean to get access to this spatial and cultural knowledge.On the other hand, physical proximity reinforces the feeling of discovery: "I know the city centre very well and I just realised that I didn't know these places [close to the cathedral] at all!' (Rosa, 60); "I liked El Ingenio a lot. I was very impressed. I didn't know it. I must have been a thousand times in this street but..." (Gloria, 39).

Secondly, physical proximity regarding the destination isn't the only characteristic of these individuals' frame of reference. Everyday practicesare important to learn about the familiarity between individual and visited areas. The main everyday practices identified in this analysis are: 
taking a stroll ["We walk a lot in this area, we come very often. We come here a lot and I just discovered the statue of the Saint there!" (Sara, 51); "I've walked a lot in these areas" (Felipe, 67)]; attending cultural events ["Actually, we know this area very well and now for Christmas we always come to Santa Llucia's market" (Beni, 64); "Every year I come to Gracia's festival" (Anna, 35)]; visiting friends and relatives ["Usually we come here to visit my parents" (Ariana, 31)]; leisure and nightlife practices ["I've lived 20 years here, now we come to the bars" (Gloria, 39); "We go to Les 7 Portes restaurant very often" (Beni, 64)]; and working ["I work here" (Clara, 25); "Now I'm retired but when I worked I used to work with foreign companies and I brought them to Barcelona's Jewish quarter" (Marc, 63)]. These everyday practices are part of the personal experiences and condition the way these individuals gaze upon the destination.

The notion of everyday implies a regularity. For example, attending cultural events every year has been included in the analysis of everyday practices, even if they are mostly unique performances. Recurring participation in these walking guided tours can therefore be considered an everyday practice: "We come to this area to participate in walking tours or to have a drink" (Gloria, 39); "We book every tour that we find interesting because of the kind of tour or because we like the area" (Carlos, 48); "Living here, every time that we see that there is a tour like this, when I have some spare time and I find it interesting, I take him and say "Let's do this because it's going to be great»" (Miquel, 29). Nevertheless, like cultural events, every walking guided tour providesa unique experience. Since it is a live performance, it can't be done and enjoyed twice as exactly the same (Colbert \& Cuadrado, 2003). Participants even combine their different experiences of walking guided tours to create their own story: "All the information you learn from the different tours, you keep on crossing it" (Carlos, 48). Participating in these tours as a regular practice clearly influences the tourist experience since these participants are at least familiar with the logistics of these tours and are more demandingthan beginners: "Look, last week I was in a tour in Raval and guides were volunteers and today is much better, the guide is a professional" (Miquel, 29); "When I'm in a tour and the guide doesn't explain things and he just reads a travel book, I feel like I miss something. I prefer to do walking tours with people who like what they do, who don't just repeat facts because they have a job and they have to do it... We've done some tours with guides that you think «Oh, my God»[...]. On the contrary, once we went to Guell Park and the guide was a nice person who explained the life of the neighbourhood and was very excited. That makes you enjoy the tour" (Carlos, 48). There might be a point of saturation where the individual feels like he already knows everything there is to know: "[With this kind of tours] I've done all the neighbourhoods in Barcelona and all the themes from the foundations till the Modernism and I just have three or four things left to do" (Carlos, 48). It is for that reason that organisers of these tours keep on innovating and new themes are launchedevery month.

In the third place, memories are considered as part of the imaginary of these places and therefore as one of the filters through which individuals gaze upon the destination and buildthe tourist experience:"Every time when I am in front of the Cathedral I remember when I went to school in Lladó street coming from Ramblas" (Amparo, 63); "My first kiss with my partner" (Maria, 50); "Dancing sardanes [traditional Catalan dance] in the Cathedral's square and dancing salsa in 
Plaça del Rei square" (Mario, 55); "Watching the final of football world championship in a bar in Raval" (Roger, 29), etc.Memories affect the experience, enhancing it or making it worse depending on how positive or negative the memory is (Tung \& Ritchie, 2011). In this case, memories reveal a familiarity with the visited areas contributing to the proximity tourist gaze.

Other aspects like social class, gender, nationality, age and education define individual's perceptions and experiences as well (Urry \& Larsen, 2011). According to the data collected during the participant observation, these are intergenerational tours. Most of the participants are between 30 and 70 years old. There hasn't been any child participating during the observations and there are tours where they aren't accepted, usually because of the theme or because these tours go through scary places. There was equality between men and women in every observed tour. Participants essentially belonged to middle class and the majority had higher education. However, there were some participants with basic education too. These aspects constitute additional filters of the tourist gaze but it is the unique combination of all of them which forms the perspective of the tourist experience.

There are also collective filters, perceived by the whole group. The ambiance around these tours is an example: street musicians, street vendors, beggars, other groups with guides, alarms from the shops, blinds closing and the sound of steps in a silent alley at night, blinds opening in the morning, good weather, bad weather, cold, heat, etc. All these elements condition the experience in a positive or negative way. Moreover, some of these aspects are staged to improve this experience. For example, there is a walking tour about crimes in Barcelona and it happens at night: "I love history. That and going out at night it's a great combination" (Jordi, 39). This way, the narrative is surrounded by a particular context which complements the way this tour is perceived. These elements are other inputs in the individual's frame of reference and in the construction of the tourist gaze.

This research is interested in the tourist gaze as a deliberate perspective adopted by participants in walking guided tours taking place in their hometown or metropolitan region. "The concept of the gaze highlights that looking is a learned ability and that the pure and innocent eye is a myth" (Urry \& Larsen, 2011, p. 1). It has been said that tourist's point of view is the result of all the elements of the individual's frame of reference (and that includes collective references interpreted by the individual) with a particular motivation based on curiosity which makes the individual more available to meet the unknown (Vacher, 2014). The analysed participants are mainly moved by curiosity and interest in knowing better the city. They know that they still have things to learn about the region where they live and they have decided to emulate tourists because tourists seem to learn about these unknown aspects more easily than residents: "Tourists come and know everything and we are here and don't know anything at all" (Marc, 63). Since tourists participate in guided tours, participating in this kind of activities seem to be an easy way to become a tourist: "I am from this neighbourhood and, well, there are a lot of things that you never get to know. However, if you go with a guide, then... It is a pity that visitors from outside, 
from abroad, know better than us. And that, us being from here, from the neighbourhood!" (Ariana, 31).

Nonetheless, unlike traditional tourists, proximity tourists' individual frame of reference includes physical and abstract proximity with the destination: on one hand it is located close to the household and, on the other hand, it feels familiar because it is the scene of everyday practices and memories. Therefore, proximity tourists and traditional tourists share the curiosity and interest as motivations but don't have the same points of reference. It has been established that every individual has his/her own depending on his/her personal experiences. Proximity tourists have in common a proximate relationship with the visited areas and traditional tourists have in common a certain distance with the destination. Therefore, according to this research, returning to Tuan's theory about the simple and the complex approach of the territory from tourists and residents(Tuan, 1990), even if proximity tourists approach the destination through a tourist perspective and, therefore, through a simple approach, they remain residents and keeptheir complex approach of the territory. On one hand, during walking tours, they appreciate the aesthetical aspects of the city that they don't notice in their everyday lives: "I've passed 50,000 times in front of those little angels with the set-square and all that and I had never seen them!" (Marc, 63) and these tours are an opportunity to confront their own society's strengths and weaknesses since all the observed tours had a critical approach of local history and myths. On the other hand, their point of view is strongly conditioned by the proximity that they hold with the visited places.Proximity tourists' approach is complex because it is built with information coming from multiple sources: personal experiences, family, work, society, environment, media, etc. Traditional tourists adopt a simpler approach because their relationship with the destination is relatively new and based on the information they collected when they prepared their tripand what they know from the media.The information that proximity tourists get from these tours is therefore automatically put into context while traditional tourists can't because they don't have the same relationship with the destination. The proximity with the destination constitutes the main filter through which proximity tourists gaze upon it.

According to the interviewed organisers, narratives of these tours are adapted to a local audience. Hence, they go deeper in the stories than walking tours offered to traditional tourists who don't know the basic historical facts of the visited society.However, traditional tourists looking for an alternative point of view also participate in these tours: "We looked for activities out of the conventional tourist circuits" (tourist from Seville, 35).During these activities, all kinds of participants share the same destination and travel through the same narrative. Traditional tourists very likely feel out of their comfort zone (Poulain, 2000) more easily than proximity touristsbut both proximity and traditional tourists perceive the experience of the tour according to their own memories and previous experiences (Tung \& Ritchie, 2011) that they had in their hometown or travelling. Furthermore, all enjoy the tours as a mean to access to the unknown. For locals, they are tools to become "the other" in a close and familiar environment. For tourists, they bring authenticity since they visit the destination by the hand of locals.In this sense, becoming either a 
traditional or a proximity tourist is a conscious decision on approachingplaces through a tourist practice.

\section{Conclusions}

Tourist studies have usually focused on the question of the subjective construction of familiarity, the process through which individuals give places a meaning(Tuan, 2011) and these places become part of the individual's usual environment (Ascher, 2000; Govers et al., 2008). This paper focuses on an opposite phenomenon which we refer to asthe subjective construction of otherness. In other words, it is the process through which individuals distance themselves from a close and familiar placein order to approach it differently.

The experiences of participants in walking guided tours in Barcelona living in its metropolitan region have been analysed. This phenomenon is developing in every metropole in the world. In a post-modern context where far realities are accessible to most people from developed countries, there is the need to look for new ways of attachment, by promoting local heritage and developing identity features, for example.

Participants analysed in this research live in the metropolitan region of Barcelona and maintain familiar links with the visited area because it is the scene oftheir everyday practices and memories. They have realized that they do not know their city enough from a spatial and a historical point of view, they have identified otherness in their perimeter of proximity. Therefore, they try to overcome this lack of knowledge by participating in guided tours which are traditionally associated with a tourist experience. These guided tours represent a marginal experience (Vacher, 2014), an experience of the otherness because they explain and show unknown and surprising aspects of the city. In other words, thanks to these activities, local population gain access to unknown parts of their hometown.In this sense, walking guided tours operate as mediation techniques between the participants and their environment(Vergopoulos, 2013).

This paper argues that it is possible to carry the process of subjective construction of otherness by deliberately adopting a tourist'spoint of view. Urry and Larsen's (2011)theory of the tourist gaze and Tuan's theory of the tourist and the resident's approaches of the territory have been adopted in order to understand what a tourist's point of view is. For these authors, looking is a "learned ability" conditioned by several frames like age, nationality, gender, education, etc.Besides, tourists are essentially motivated by curiosity and interest. Therefore, tourist's point of view is here considered as a mix of the individual's frame of reference and curiosity.Individual's frame of reference includes all the subjective and collective elements conditioning the experience. According to the preliminary results of this research, these participants, like tourists, are mainly motivated by curiosity. However, unlike tourists, their strong relationship of proximity with the visited areas highly determines their frames of reference. It is in this sense that they are called proximity tourists. Traditional tourists participate in these walking guided tours looking for authenticity and proximity tourists do it to visit the city like tourists do.In this sense, participating 
in a tourist practice is a conscious decision.For both kinds of participants these tours are a mean of meeting the otherness.

Not all local participants look for a tourist experience. Four modes of experience of these walking tours have been identified: educational, expert, recreational and tourist. The educational experience refers to those participants whose main motivation is to learn. For them, participating in a walking guided tour is like going to a lecture but more enjoyable. The expert experience happens when the participant wants to confirm his/her own knowledge. This mode has great impact on the experience of the rest of the group. The recreational experience is for those who essentially want to have a good time without any further motivation. Finally, the tourist experience in this case concerns those participants who explicitly declarethat these walking guided tours are tools to learn about their hometown the way tourists do. These categories are not exclusives since the same participant has different experiences in different tours or even within the same tour.

These are preliminary results of an ongoing research. They aimed to introduce the approach of proximity tourism in a close and familiar destination. More research has to be done regarding the impacts of these practices in the public space in terms of image and attachment ofindividuals to their home region. Moreover, future research as well as land planners can benefit from this approach on the subjective construction of the otherness to develop proximate destinations.

\section{Bibliography:}

AFP Relax News (2012). South Africans rediscover once-feared downtown Johannesburg; once riddled with crime, area now deemed safer. Retrieved from http://www.nydailynews.com/life-style/south-africans-rediscover-once-feared-downtownjohannesburg-riddled-crime-area-deemed-safer-article-1.1055198

Aguas, J.-C., \& Gouyette, B. (2011). L'invention d'un tourisme de l'ordinaire. L'exemple des Promenades urbaines [The invention of an ordinary tourism. The example of Promenades Urbaines]. Espaces, tourisme et loisirs, 292, 8- 13.

Arrieta Urtizberea, I., Hernández León, E., \& Andreu Tomàs, A. (2016). Patrimonio local en un mundo global: procesos de patrimonialización cultural en contextos locales de Andalucía y el País Vasco [Local heritage in a global world: Heritagization of culture in Andalusian and Basque local contexts]. Memória em Rede, 8(14), 41- 57. doi: 10.15210 
Ascher, F. (2000). La société hypermoderne [Hypermodern society]. La Tour d'Aigues: L'Aube.

Beaucham-Aligny, M., Houvenaghel, F., \& Wilhelm, S. (2011). Rallyes urbains à Roubaix. De la réappropriation du territoire à l'émergence d'un tourisme alternatif [Urban tours in Roubaix. From the re-appropriation of territory to the emergence of an alternative tourism]. Espaces, tourisme et loisirs, 292, 21- 24.

Boschma, R. (2004). Proximité et innovation [Proximity and innovation]. Économie Rurale, 280, 8- 24.

Bossé, A. (2010). L'expérience spatiale de la visite [The visit's spatial experience]. Université François-Rabelais, Tours. Retrieved from http://www.applis.univtours.fr/theses/2010/anne.bosse_2990.pdf

Boudelaire, C., \& Cova, B. (2008). Attiser le feu du jeu postmoderne : le cas du geocatching et de ses zones liminoides [Fanning the fire of post-modern game: the case of geocaching and its limoid zones]. Sociétés, 4, 69-82.

Bourdeau, P. (2009). From après-ski to après-tourism: the Alps in transition? Reflections based on the French situation. Revue de géographie alpine| Journal of Alpine research, 97(3). doi: 10.4000/rga.1054

Bourdeau, P. (2013). Introduction : Interroger les mutations et les recompositions en cours [Introduction: Questioning the ongoing mutations and recompositions]. In H. François, P. Bordeau, \& L. Perrin-Bensahel (Eds.), Fin (?) et confins du tourisme : interroger le statut et les pratiques de la récréation contemporaine [End(?) and outer limits of tourism: questioning the status and practices of contemporary recreation] (p. 17- 42). Paris: L'Harmattan. 
Bryon, J. (2012). Tour guides as storytellers: from selling to sharing. Scandinavian Journal of Hospitality and Tourism, 12(1), 27- 43. doi: 10.1080/15022250.2012.656922

Callot, P. (2013). Tourisme après-pétrole : des préférences au scénario le plus probable. Une tentative d'exploration [Tourism after the end of cheap oil: From personal preference to most likely scenario. An exploratory study]. Mondes en développement, 3(163), 131-142. doi: 10.3917/med.163.0131

Christin, R. (2008). Manuel de l'antitourisme [Guide of anti-tourism]. Paris: Yago.

Cohen, E. (1979). A phenomenology of tourist experiences. Sociology, 13(2), 179- 201. doi: $10.1177 / 003803857901300203$

Colbert, F., \& Cuadrado, M. (2003). Marketing de las artes y la cultura [Marketing of arts and culture]. Barcelona: Ariel.

Davis, A. (2016). Experiential places or places of experience? Place identity and place attachment as mechanisms for creating festival environment. Tourism management, 55, 49- 61. doi:10.1016/j.tourman.2016.01.006

De Guzman, N. (2014). Rediscover Metro Manila [Blog]. Retrieved from http://www.spot.ph/things-to-do/57301/10-walks-and-tours-for-rediscovering-metromanila

Dubois, G., \& Ceron, J.-P. (2006). Tourism/Leisure Greenhouse Gas Emissions Forecasts for 2050: Factors for Change in France. Journal of Sustainable Tourism, 14(2), 172- 191. doi: 10.1080/09669580608669051

Dubois, G., Peeters, P., Ceron, J.-P., \& Gössling, S. (2011). The future tourism mobility of the world population: Emission growth versus climate policy. Transportation Research Part A: Policy and Practice, 45(10), 1031- 1042. doi: 10.1016/j.tra.2009.11.004 
Edensor, T. (2001). Performing tourism, staging tourism. (Re)producing tourist space and practice. Tourist studies, 1(1), 59- 81. doi: 10.1177/146879760100100104

Esteban, J. (2003). La Regió Metropolitana de Barcelona [The metropolitan región of Barcelona]. Papers, 39, 31- 41.

Fabry, N., Picon-Lefebvre, V., \& Pradel, B. (2015). Introduction. In N. Fabry, V. PiconLefebvre, \& B. Pradel (Eds.), Narrations touristiques et fabrique des territoires: Quand tourisme, loisirs et consommation réécrivent la ville [Tourist narratives. When tourism, leisure and consumption rewrite the city] (p. 5- 18). Paris: L'oeil d'or.

Florida, R. (2008). Who's your city?Basic Books.

Gellereau, M. (2005). Entre récit scientifique et récit de fiction : le discours sur le «pays noir » dans l'accompagnement des visiteurs sur les sites miniers [Between scientific and fiction narratives: the story of the "black country"]. Revue du Nord, 2(360- 361), 545- 554. doi: $10.3917 / \mathrm{rdn} .360 .0545$

Geva, A., \& Goldman, A. (2008). Satisfaction measurement in guided tours. Annals of tourism research, 18(2), 177- 185. doi: 10.1016/j.annals.2008.09.001

Govers, R., Van Hecke, E., \& Cabus, P. (2008). Delineating tourism. Defining the usual environment. Annals of tourism research, 35(4), 1053- 1073. doi: 10.1016/j.annals.2008.09.001

Guàrdia, L. (2010). Barcelona Visió 2020, una proposta estratègica [Barcelona Horizon 2020, a strategic proposition]. Barcelona: Associació Pla Estratègic de Barcelona. Retrieved from http://www.pemb.cat/public/docs/13_0a_pemb2020catweb.pdf 
Guedon, J. (2005). Approches de la notion de proximité en sciences sociales [Approaches of the notion of proximity in social sciences]. Cahier de recherche en management, 36. Retrieved from http://www.ecole-management-normandie.fr/upload/editeur/CR36.pdf

Haldrup, M., \& Baerenholdt, J. O. (2011). Tourist experience design. In J. Simonsen, J. O. Baerenholdt, M. Büscher, \& J. D. Scheuer (Eds.), Design research: synergies from interdisciplinary perspectives (p. 187- 200). Londres, New York: Routledge.

Haldrup, M., \& Larsen, J. (2009). Tourism, performance and the everyday: consuming the Orient. Londres: Routledge.

Hughes, K. (1991). Tourist satisfaction: A guided « cultural » tour in north queensland. Australian psychologist, 26(3), 166- 171. doi: 10.1080/00050069108257243

Jackson, M., White, G. N., \& Schmierer, C. L. (1996). Tourism experiences within an attributional framework. Annals of tourism research, 23(4), 798- 810. doi: 10.1016/01607383(96)00003-5

Jane's walk (http://janeswalk.org/information/about/janes-walk/)

Jeuring, J. H. G. (2015). Discursive contradictions in regional tourism marketing strategies: the case of Fryslân, The Netherlands. Journal of destination marketing \& management. doi: 10.1016/j.jdmm.2015.06.002

Jiménez, S., \& Prats, L. (2006). El turismo en Cataluña: evolución histórica y retos de futuro [Historical evolution and future challenges of tourism in Catalonia]. Pasos. Revista de turismo y patrimonio cultural, 4(2), 153- 174. Retrieved from http://www.pasosonline.org/Publicados/4206/PS030206.pdf

Jonasson, M., \& Scherle, N. (2012). Performing co-produced guided tours. Scandinavian Journal of Hospitality and Tourism, 12(1), 55- 73. doi: 10.1080/15022250.2012.655078 
Karrbom Gustavsson, T., \& Hallin, A. (2013). Guiding in the city of tomorrow: materializing the future through future and present components. Scandinavian Journal of Hospitality and Tourism, 13(2), 127- 138. doi: 10.1080/15022250.2013.796226

Larsen, J., \& Widtfeldt Meged, J. (2013). Tourists co-producing guided tours. Scandinavian Journal of Hospitality and Tourism, 13(2), 88- 102. doi: 10.1080/15022250.2013.796227

Le Breton, D. (2000). Eloge de la marche [Walking's eulogy]. Paris: Métailié.

Promenades Urbaines (http://www.promenadesurbaines.com/modules/content/index.php?id=22\&page=missions)

Maunder, P. (2012). Unveiled, step by step [Blog]. Retrieved from http://www.theage.com.au/entertainment/about-town/unveiled-step-by-step-201201191q7v8.html

Pearce, P. (2012). The experience of visiting home and familiar places. Annals of tourism research, 39(2), 1024- 1047. doi: 10.1016/j.annals.2011.11.018

Pearce, P., \& Kang, M. (2009). The effects of prior and recent experience on continuing interest in tourist settings. Annals of Tourism Research, 36(2), 172- 190. doi: 10.1016/j.annals.2009.01.005

Petiteau, J.-Y., \& Pasquier, E. (2001). La méthode des itinéraires t récits et parcours [The method of itineraries: narratives and paths]. In M. Grosjean \& J.-P. Thibaud (Eds.), L'espace urbain en méthodes [Urban space in methods] (pp. 63- 78). Marseille: Parenthèses.

Poulain, J.-P. (2000). Les patrimoines gastronomiques et leurs valorisations touristiques [Gastronomic heritage and its valorisation for tourism]. In R. Amirou \& P. Bachimon (Eds.), Le tourisme local [Local tourism] (pp. 157- 184). Paris: L'Harmattan. 
Pradel, B., Simon, G., \& Lefrançois, D. (2015). L'influence du tourisme sur l'expérience quotidienne de la mobilité. Le cas du RER A entre Paris et Disneyland [The influence of tourism on the everyday experience of mobility]. In N. Fabry, V. Picon-Lefebvre, \& B. Pradel (Eds.), Narrations touristiques et fabrique des territoires. Quand tourisme, loisirs et consommation réécrivent la ville [Tourist narratives. When tourism, leisure and consumption rewrite the city] (pp. 181-202). Paris: L'oeil d'or.

Prebensen, N. K., \& Joar Vitterso, T. I. D. (2013). Value co-creation significance of tourist resources. Annals of tourism research, 42, 240- 261. doi: 10.1016/j.annals.2013.01.012

Schütz, A. (1987). Le chercheur et le quotidien: Phénoménologie des sciences sociales [The researcher and the everyday life: phenomenology of social sciences]. Paris: Klincksieck.

Selby, M. (2004). Consuming the city: conceptualizing and researching urban tourist knowledge. Tourism Geographies, 6(2), 186- 207. doi: 10.1080/1461668042000208426

Smith, M., MacLeod, N., \& Hart Robenson, M. (2010). Key concepts in Tourist Studies. Londres: SAGE.

Smith, S. L. J. (1999). How far is far enough? Operationalizing the concept of usual environment in tourism definitions. Tourism Analysis, 4(3/4), 137- 143. doi: 1083-5423/00

Sogues, M. (2010). Pla territorial parcial de la regió metropolitana de Barcelona [Blog]. Retrieved from http://territori.scot.cat/cat/notices/2010/12/pla_territorial_parcial_de_la_regio_metropolita na_de_barcelona_2634.php

Stock, M. (2007). Théories de l'habiter: Questionnements [Theories of inhabiting: Questions]. In M. Lussault, T. Paquot, \& C. Younès (Eds.), Habiter, le propre de l'humain: Villes, 
territoires et philosophie [Living, proper to the human: Cities, territories and philosophy]. Paris: La découverte.

Suñé, R., \& Sierra, E. (2015). Ada Colau: El modelo Barcelona se ha de mantener pero es mejorable [Ada Colau: "Barcelona's model has to go on but it can be improved"]. $L a$ Vanguardia. Retrieved from http://www.lavanguardia.com/politica/20150711/54433347514/ada-colau-modelobarcelona-mantener-mejorable.html

Taylor, S. J., \& Bogdan, R. (1987). Introducción a los métodos cualitativos de investigación [Introduction to qualitative methods of research]. Barcelona, Buenos Aires, Mexico: Paidós.

Torré, A. (2004). Introductions : Proximité et territoires [Introduction: proximity and territories]. Économie Rurale, 280, 2- 7. Retrieved from www.persee.fr/doc/ecoru_00130559_2004_num_280_1_5467

Tuan, Y. F. (1990). Topophilia. A study of environmental perception, attitudes and values. New York: Columbia University Press.

Tuan, Y. F. (2011). Space and place. The perspective of Experience. Minneapolis: University of Minnessota Press.

Tumola, C. (2012). Rediscover Queens with a walking tour [blog]. Retrieved from http://qns.com/story/2012/07/12/rediscover-queens-with-a-walking-tour/

Tung, V. W. S., \& Ritchie, J. R. B. (2011). Exploring the essence of memorable tourism experiences.Annals of tourism research, 38(4), 1367- 1386. doi: 10.1016/j.annals.2011.03.009

Turisme de Barcelona, Diputació de Barcelona, \& Barcelona City Council (2015). Estadístiques de turisme a Barcelona i comarques. 2014. [Tourism statistics in Barcelona and regions. 
2014]. Barcelone: Turisme de Barcelona, Diputació de Barcelona, Ajuntament de Barcelona. Retrieved from http://professional.barcelonaturisme.com/imgfiles/estad/Est2014.pdf

Villes et Pays d'Art et d'Histoire (http://www.vpah.culture.fr/label/label.htm)

Urbain, J.-D. (2002). L'idiot du voyage. Histoires de touristes [The idiot of travelling. Histories of tourists]. Paris: Payot.

Urry, J., \& Larsen, J. (2011). The tourist gaze 3.0 (3rd ed.). Los Angeles, CA: SAGE.

Vacher, L. (2014). Réflexion géographique sur la distance, une approche par les pratiques de tourisme [Geographical reflection on distance, an approach through tourism practices] (Unpublished Habilitation to conduct researches dissertation). Université d'Angers, Angers.

Vergopoulos, H. (2013). Être touriste chez soi. Le tourisme comme modèle socioculturel d'appropriation du territoire quotidien [Being a tourist at home. Tourism as a sociocultural model of appropriation of everyday territory]. In H. François, P. Bourdeau, \& L. Perrin-Bensahel (Eds.), Fin(s) et confins du tourisme $[$ End(s) and limits of tourism: questioning the status and practices of contemporary recreation] (pp. 53- 62). Paris: L'Harmattan.

Vergopoulos, H., \& Flon, E. (2012). L’expérience touristique dans les guides : une subjectivité à lire, écrire et raconter [Tourist experience through travel guides: Reading, writing and telling a subjectivity]. Belgeo, 3. Retrieved from https://belgeo.revues.org/7173

Vlès, V. (2011). Entre redynamisation urbaine et banalisation des espaces : tensions et enjeux de l'urbanisme touristique [Between urban redynamisation and banalization of spaces: tensions and stakes of tourist urbanism]. Mondes du tourisme, 3, 14- 25. Retrieved from https://halshs.archives-ouvertes.fr/halshs-00681501/document 
Widtfeldt Meged, J. (2010). The guided tour: a co-produced tourism performance. Roskilde University, Dinamarque. Retrieved from http://www.rucsdigitaleprojektbibliotek.dk/bitstream/1800/5912/5/1.phd_Jane_Widtfelt_ Megad_\%2882179\%29small_\%5b1\%5d.pdf

WTO (2014). Glossary of terms. Retrieved from https://s3-eu-west1.amazonaws.com/staticunwto/Statistics/Glossary+of+terms.pdf

Zillinger, M., Jonasson, M., \& Adolfsson, P. (2012). Guided tours and tourism. Scandinavian Journal of Hospitality and Tourism, 12(1), 1- 7. doi: 10.1080/15022250.2012.660314 